\title{
Spirit Lodge, a North American Shamanistic Séance
}

\author{
by $\AA$ KE HULTKRANTZ
}

\section{General Remarks on North American Shamanism}

In its more limited sense shamanism is a phenomenon characteristic of the North Eurasian peoples. We may then define it as a religious and magic complex centered on the ecstatic magician, the shaman. ${ }^{1}$ In a more general sense, however, shamanism is supposed to include all activities peculiar to the medicine-man. Anglo-Saxon and French scholars in particular interpret shamanism in this broader aspect. The result is that all manifestations of the American medicine-men may be called shamanism, and shamanistic. ${ }^{2}$

If the word shamanism seems ambiguous, the word shaman is less so. Most scholars agree that the activities of the shaman presuppose some form of ecstasy. Eliade, for instance, finds that the shaman is distinguished from the medicine-man, the magician and the sorcerer "by a magico-religious technique which is in a way exclusive to him and which may be called: the ecstatic trip to Heaven, to the Lower World, or to the depths of the ocean". ${ }^{3}$ It seems to me, however, that this definition is too limited; it is at least as characteristic for the shaman to operate without any extra-corporeal journey to the other world, provided he is in an ecstatic state. A shaman is, according to this definition, a practitioner who, with the help of spirits, cures the sick

1 Some scholars consider shamanism to be a religion; Findeisen, for instance, thinks that it is a "spiritualistic religion", see H. Findeisen, "Das Schamanentum als spiritistische Religion" (Ethnos r960: $3^{-4}$ ), pp. $192 \mathrm{ff}$. As pointed out by Stiglmayr this interpretation is incorrect, see E. Stiglmayr, "Schamanismus, eine spiritistische Religion?" (Ethnos r 962), pp. $47 \mathrm{f}$.

2 Cf. $\AA$. Hultkrantz, Les Religions des Indiens primitifs de l'Amérique, essai d'une synthèse typologique et historique (Acta Universitatis Stockholmiensis, Stockholm Studies in Comparative Religion, vol. 4, 1963), pp. $84 \mathrm{ff}$.

${ }^{3}$ M. Eliade, "Shamanism" (Forgotten Religions, ed. V. Ferm, New York 1950), p. 299. 
or reveals hidden things etc. while being in an ecstasy. During the trance he may leave his own body, or he may simply summon the spirits to him and ask them to help him.1 This extension of the meaning of the term "shaman" is important, for it allows of the inclusion of the "Spirit Lodge" to be described in the following among the true shamanistic rites.

There are many references to shamans or "jugglers" in the early sources on North American religion, for instance in the Jesuit relations, and the material on shamanism has accumulated in the course of the centuries. Nevertheless, research on shamanism has scarcely more than begun, and we still lack a general treatise on the North American medicine-man and shaman which absorbs the whole complex of shamanism in its manifold morphology. A good start was made shortly after the turn of the century when Roland Dixon wrote his famous article on the American "shaman" (by which term he understood the medicine-man in general). Dixon has here outlined the North American shamanistic complex and mentions, among other things, the Spirit Lodge phenomenon. ${ }^{2} \mathrm{He}$ also makes the important statement that "the spiritual flight of the shaman himself, in search of information, so characteristic of the shamans in northeastern Siberia, seems on the whole rare". ${ }^{3}$ Here lies indeed the greatest difference between North American and Siberian shamanism, the latter term used in its more restricted sense.

Dixon's good initiative had unfortunately no immediate following. Instead, attention was concentrated on the characteristically North American vision quest, particularly after Benedict had published her famous work on the guardian spirit.4 This vision-seeking was named "democratized shamanism"

${ }^{1}$ Cf. J. Haekel, "Religion" (Lehrbuch der Volkerkunde, ed. by L. Adam and H. Trimborn, Stuttgart 1958), pp. $62 \mathrm{f}$.

2 R. B. Dixon, "Some Aspects of the American Shaman" (Fourn. of Amer. FolkLore, vol. 21, 1908), p. 9.

3 Dixon, loc. cit.

1 R. F. Benedict, The Concept of the Guardian Spirit in North America (Amer. Anthrop. Ass., Mem., vol. 29, I923); idem, "The Vision in Plains Culture" (Amer. Anthrop., vol. 24: I, I922), pp. I ff.; J. Blumensohn, "The Fast among North American Indians" (Amer. Anthrop., vol. 35: 4, I933), pp. 45 I ff.; J. Haekel, "Zum Problem des Individualtotemismus in Nordamerika" (Intern. Arch. für Ethnogr., vol. 35,1938 ), pp. 35 ff. Cf. also the survey in Hultkrantz, op. cit., pp. 7 I ff. It should be observed that Benedict presents a subchapter on shamanism in which she discusses the position of the medicine-man and shaman in relation to the common visionary (Benedict, op. cit., pp. 67 ff.). 
by Lowie, and undoubtedly represents a heritage from an older shamanistic practice. ${ }^{1}$ Shamanistic studies were, however, resumed in the late twenties and early thirties with extensive monographs on North American Indian shamanism by Leh and Corlett. ${ }^{2}$ These are not, however, exhaustive, nor do they treat the really essential features of the shaman and his art. Later works by Ohlmarks, Bouteiller and Eliade stress the parallels between North American shamanism and shamanism in the Old World from psychological, phenomenological and "religiously interpretative" points of view. ${ }^{3}$ Finally, a German doctoral dissertation, unpublished and inaccessible to the present writer, discusses the sub-Arctic forms of North American shamanism.4

Besides these general works on North American shamanism there are numerous others dealing with selected aspects of shamanism, as Stewart's investigations of possession, 5 or with shamanism in particular tribes, as Park's treatises of Paviotso shamanism. ${ }^{6}$ There are also many studies of the integration of shamanism in modern American Indian cults, such as shakerism.7 Strangely enough, the shamanistic background of the Ghost-dance

1 Cf. R. Lowie, An Introduction to Cultural Anthropology (New York r940), p. 3I2; Hultkrantz, op. cit., pp. $74 \mathrm{ff}$., 77 . A contrary opinion will be found in $M$. Schuster, "Die Schamanen und ihr Ritual" (Völkerkunde, ed. by B. Freudenfeld, München i 960), pp. $36 \mathrm{ff}$.

2 L. L. Leh, The Shaman in Aboriginal American Society (Univ. of Colorado Studies, vol. 20, I 934), pp. 199 ff.; W. T. Corlett, The Medicine-Man of the American Indian (Springfield r935). See also A. C. Parker, "Indian Medicine and Medicine Men" (Ann. Archaeol. Rep., Toronto 1928), pp. $9 \mathrm{ff}$.

3 A. Ohlmarks, Studien zum Problem des Schamanismus (Lund 1939); M. Bouteiller, Chamanisme et guérison magique (Paris 1950); M. Eliade, Le Chamanisme et les techniques archaïques de l'extase (Paris $195 \mathrm{I}$ ), particularly pp. $26 \mathrm{I} \mathrm{ff}$.

4 S. Bechmann, Der Schamanismus bei den Indianern des subarktischen Amerika (Wien I958).

5 K. M. Stewart, "Spirit Possession in Native America" (Southw. Gourn. of Anthrop., vol. 2: 3, I946), pp. 323 ff.; idem, "Spirit Possession" (Tomorrow, vol. 4: 3, I956), pp. 4 I ff.

6 W. Z. Park, Shamanism in Western North America (Chicago 1938); idem, "Paviotso Shamanism" (Amer. Anthrop., vol. 36: I, 1934), pp. $98 \mathrm{ff}$.

7 T. T. Waterman, “The Shake Religion of Puget Sound" (Ann. Rep., Smithsonian Inst., r922, Washington r924), pp. 499 ff.; E. Gunther, The Shaker Religion of the Northwest (Columbia Univ. Contrib. to Anthrop., vol. 36, New York 1949), pp. 37 ff.; J. M. Collins, "The Indian Shaker Church" (Southw. Fourn. of Anthrop., vol. 6: 4, I950), pp. $399 \mathrm{ff}$.; M. W. Smith, "Shamanism in the Shaker Religion of Northwest America" (Man, vol. 54, I954), pp. I 9 ff.; H. G. Barnett, Indian Shakers (Carbondale 1957). 
movement has not as yet received an adequate and thorough investigation. ${ }^{1}$

It is well known even among scholars who are not Americanists that shamanism in North America sometimes appears in very specific forms, particularly where shamanistic societies have developed; it is sufficient to remind the reader of the medicine-lodge society among the Central Algonkian tribes and the cannibal society among the Kwakiutl. ${ }^{2}$ In the present article, however, interest is concentrated on the more original, individualistic forms of shamanism, and whenever shamanism is mentioned it is the activities of the lone practitioners which are referred to. It is less well known but nevertheless a fact that also this individualistic shamanism appeared and continues to appear in several different forms.

The regional typology of North American shamanism is rather complicated and still needs a thorough analysis, although the authors mentioned above have made some progress in trying to reveal the pattern. If, however, we apply broad historical-phenomenological perspectives, we may observe a major difference between two main forms: first, a type of shamanism which is very common also in other parts of the world, and is characterized by considerable variation but (usually) low intensity in its forms of expression; and, secondly, a more limited shamanism which is characterized by its uniformity and intensity. In this paper, I shall call the former type "general shamanism", the second, "Arctic shamanism", since it dominates the Arctic areas (the Eskimo) and parts of the Northwest Coast area and most probably has direct connections with similar shamanistic manifestations in the Arctic areas west of Bering Strait. There is no doubt that Arctic shamanism has developed on the foundations of general shamanism. It may be defined as an ecologically conditioned special form of the latter. This does not exclude, however, that also a common Circumpolar historical tradition has contributed to its growth. ${ }^{3}$

${ }^{1}$ Cf., however, $\AA$. Hultkrantz, The North American Indian Orpheus Tradition (Statens Etnogr. Mus., Monogr. Ser., vol. 2, Stockholm I957), pp. 306 f., 3 I I f.

2 Survey and short bibliography in Hultkrantz, Les Religions des Indiens etc., pp. II4 ff.

3 A. Hultkrantz, "Type of Religion in the Arctic Hunting Cultures: A ReligioEcological Approach" (Hunting and Fishing, Nordic symposium on life in a Traditional Hunting and Fishing milieu in Prehistoric Times and up to the Present Day, Luleå I965), pp. $265 \mathrm{ff}$. 
In general shamanism, ecstasy does not function as a constantly prevailing factor. The medicine-man has, perhaps, attained his profession through an ecstatic experience in which the guardian spirits have appeared and delegated their power to him; in his shamanistic activity, however, he can operate without falling into a trance - in some cases he is even unable to enter into ecstasy. Since his activities are mostly directed to the curing of diseases (every shaman and medicine-man is first and foremost a healer), he has recourse to healing methods which do not demand a higher degree of meditation: extraction and sucking of disease spirits and objects from the inflicted person's body are primarily resorted to, less often extraphysical journeys to catch a strayed or stolen soul. If the diagnosis of soul loss is inescapablewhich it usually is when the consciousness of the sick person is darkenedthe medicine-man has several ways of retrieving the lost soul. He can, for instance, show in a pantomime how he seeks it in the environment or how he catches it in the realm of the dead. There are also occasions, at least in some places, when, during an ecstasy, he dispatches his own free-soul to overtake the forlorn soul of his patient. In most cases, however, the shaman's trance is reserved for the summoning of his assistant spirits. These are called on for consultation or active intervention, be it the curing of the sick, the finding of lost articles or the discovery of secrets and of future events.

In Arctic shamanism the trance is an integral part of the shamanistic procedure. The shaman resorts to ecstasy, either to recall the sick person's soul, to remove a disease-object from the patient's body, or to gather information concerning human beings and fateful events. During the ecstasy he usually sends out his free-soul, or his guardian spirits-the boundary-line between these spiritual agents often tends to be effaced, the shaman being able to journey in the figure of his guardian spirit. When the shaman cures a patient whose disease is caused by the intrusion of an inanimate object or a spirit (a diagnosis which somehow is forced aside in Arctic shamanism), he usually lives in a kind of half trance and is assisted by his helping spirits. The notion exists sometimes that the latter, and not the shaman, remove the disease agent.

This summarily sketched outline of the two most prominent forms of shamanism in North America will serve as a background and help us to put in its right place the shamanistic performance which will be described 
in what follows. In the bordering area between general and Arctic shamanism we find a ritually elaborated shamanistic séance characterized by the summoning of spirits for information (divination, etc.) and, in some cases, healing. It is held in a dark place, and the medicine-man is not infrequently practising in a cylindrical tent erected for the purpose. This may be placed outdoors or in a largish lodge or house. Sudden confusion of spirit voices, shaking of the tent and the medicine-man's mysterious disentangling of ropes and thongs are some of the most conspicuous features of the performance. It is known under the denominations "Shaking Tent" and "Spirit Lodge", or is simply described as "Conjuring Ceremony" or "Jugglery". Since the feature of the shaking tent is not present everywhere in this ceremony, particularly not in the Arapaho séance to be described here, the term "Spirit Lodge" is preferred in this article. The ceremony has been dealt with from different points of view by authors like Cooper, Hallowell, Lambert and Ray.1 Its religiohistorical position has, however, never been made the object of a closer investigation.

\section{A Spirit Lodge Ceremony among the Arapaho Indians}

In August 1955, the present author attended a medicine ceremony among the Arapaho Indians on the Wind River Reservation, Wyoming. The Arapaho constitute a branch of the great Algonkian linguistic stock; their nearest kinsmen are the Atsina or Gros Ventre (of the Plains) who broke away from them several hundred years ago. They were, until the end of last century, typical Plains Indians equipped with horses and tipis (i.e., conical tents of buffalo-hides), living on buffaloes, organized with military societies, and having the famous Sun Dance as their foremost religious expression. With their well-known neighbours and linguistic kin, the Cheyenne, and the likewise well-known northern Sioux (Dakota) Indians, they were until late times among the most warlike tribes on the Northern Plains. It was a close

1 J. M. Cooper, "The Shaking Tent Rite among Plains and Forest Algonquians" (Prim. Man, vol. 17: 3-4, 1944), pp. 60 ff.; A. I. Hallowell, The Role of Conjuring in Saulteaux Society (Publ. of the Philadelphia Anthrop. Soc., vol. 2, Philadelphia I942); R. S. Lambert, "The Shaking Tent" (Tomorrow, vol. 4: 3, I956), pp. Ir3 ff.; V. F. Ray, "Historic Backgrounds of the Conjuring Complex in the Plateau and the Plains" (Language, Culture, and Personality: Essays in Memory of Edward Sapir, ed. L. Spier et alii, Menasha, Wis., I94I), pp. $204 \mathrm{ff}$. 
common interest, viz. the opposition to the white invaders, which brought them and the Sioux together; and the bands between the two tribes are still rather strong, as will appear from the following account. It is also important to note that the Arapaho have always been known as devotedly religious; their inclination to religious mysticism distinguished them from most other Plains tribes. In 1878 they were removed by force from their old hunting grounds in eastern Wyoming and western Colorado to their present home in western Wyoming.1

Anyone who knows the Arapaho's strong dedication to religion would expect the medicine ceremony to be performed by some of their old medicinemen. This strangely enough was not the case. The acting medicine-man was an Oglala Sioux from the Pine Ridge Reservation in South Dakota by the name of Mark Big Road. Although a very silent and reticent man-he did not like to discuss the ceremony with me-he nevertheless disclosed certain particulars about himself and his calling. Mark Big Road, a tall and strongly built man in his forties, told me that he practised the same type of séance as his father and grandfather had done before him. They were medicine-men like him, and Mark had inherited their guardian spirits. In spite of this, however, he had not acquired them automatically but had like other medicinemen to go through an ordeal of fasting and waking, whereupon the spirits had appeared in visions. His foremost helping spirit was Skadi, the ghost of a white man who had become so "indianized" that he now spoke the Sioux language. Mark had met Skadi in his first vision, and then after Skadi's instructions he had received many other guardian spirits, he did not say how many. An Arapaho woman who considered herself initiated told me they were 427 all in all, other participants in the ceremony thought they were

1 Cf. J. Mooney, "The Ghost-Dance Religion and the Sioux Outbreak of 1890 " (Bur. of Amer. Ethnol., Ann. Rep. 14: 2, Washington 1896), pp. 953 ff.; idem, "Arapaho" (Handbook of American Indians North of Mexico, ed. F. W. Hodge, Bur. of Amer. Ethnol., Bull. 30: 1, Washington 1907), pp. 72 f.; A. L. Kroeber, "The Arapaho" (Amer. Mus. of Nat. Hist., Bull. XVIII: I, New York 1902), pp. I ff.; W. P. Clark, The Indian Sign Language (Philadelphia I885), pp. 38 ff.; Sister M. I. Hilger, "Arapaho Child Life and Its Cultural Background" (Bur. of Amer. Ethnol., Bull. I48, Washington I952), pp. I ff.; H. Elkin, "The Northern Arapaho of Wyoming" (Acculturation in Seven American Indian Tribes, ed. R. Linton, New York 1940), pp. 207 ff.; M. H. Wright, $A$ Guide to the Indian Tribes of Oklahoma (Norman 1951), pp. $42 \mathrm{ff}$. 
many but would not say how many. One spirit is supposed to be 7000 years old. Mark counts among his guardian spirits also the mighty spirit of the Thunder (Wakinyan).

Mark Big Road had been called to Wind River by Arapaho Indians who had witnessed his magical performances on the Sioux reservation and among white men in Rapid City. Older Arapaho remembered that similar remarkable feats had been achieved amongst them fifty years earlier, or around that time. However, no present-day medicine-man among them mastered the art any longer. Therefore, Mark was called upon to reintroduce the medicine ceremony during a series of performances. Admittedly, this meant that the Oglala version of the ritual had to be accepted, but the difference between this and the earlier indigenous ceremony was apparently very slight. Anyway, this reintroduction of an old shamanistic rite must be considered to be a remarkable event, particularly if we keep in mind that seventy-five years earlier the Indian agent at Fort Washakie (Wind River Reservation) thought he could report that the Arapaho medicine-men had finally ceased with their jugglery. ${ }^{1}$ In other words, the revitalized medicine ceremony among the Arapaho in the 1950's ought to be conceived as a "nativistic" rite, according to Linton's definition of the concept. ${ }^{2}$ It thus represents a new trend in the tribal life, a renaissance and renewal of the best values in the old religion. In this connection it is important to note the role and functions of the medicine ceremony. It does not only help human beings to have their health restored, or their lost and hidden things regained. It also creates for them the contact with the reassuring world of spirits which is the heritage of the Indian religions since time immemorial.

The medicine ceremony on the eve of August 23, 1955, was arranged by one of the most active promoters of a religious renewal among the Arapaho, Buster Crispin, and was given for the benefit of his kinsman Steve Duran, who for many years had felt pains each time he had a meal. The ceremony was held in a primitive log-cabin close to the Little Wind River, ordinarily occupied by a middle-aged Arapaho Indian. In the course of the evening many Arapaho arrived at the house, until finally its large room was filled

1 Report of the Commissioner of Indian Affairs, I88I (Washington I88I), p. 242 (Shoshone and Bannack Agency, Wyoming).

2 R. Linton, "Nativistic Movements" (Amer. Anthrop., vol. 45: 2, т943), p. 230. 
up by some sixty persons, mostly women and children. They sat down on blankets spread out on the floor along the walls, the men being seated in the western and the women in the eastern parts of the room. Four drummers placed themselves on two mattresses in front of the men's row. Mark, appearing in the usual modern Indian apparel of "cowboy fashion", took his seat at a place where the men's and the women's sides joined each other. The windows were covered by sackcloth. It was now ten o'clock. The séance could begin.

The hostess, Helen Crispin, hands over in a dignified way a big ceremonial pipe to the medicine-man, asking him at the same time, with tears glittering in her eyes, to cure her sick relative. ${ }^{1}$ Mark accepts the pipe, lights it and starts smoking. This is a sure sign that he has decided to accede to Helen's wishes. Helen's husband now rises from his seat and admonishes those present to try to believe, not to doubt, not to wonder; they must pray incessantly to the ninety-six spirits who will be present during the performance.2 "And", he surprisingly finishes his speech, "I ask for the blessings of God and the Holy Ghost'. Hot stones are now carried in a tub to the middle of the room, water is poured over them, and the room is filled with steam and strong heat. Men and women rise and, passing slowly the heated place, they fan the steam up towards face and breast. This being done everybody receives small seeds of sweetsage which they rub into their heads and arms. This rubbing procedure as well as the steam bath are preparatory cleaning rites. ${ }^{3}$

The medicine-man now takes his seat in the centre of the room on a carpet which is covered by long straws of sagebrush. Around him are placed small flags and a rectangular enclosure, consisting of a string which is bound

1 All conversation during the performance was held in English, since Mark, being a Sioux, does not understand the Arapaho language.

2 Already before the ceremony began Buster Crispin tried to dissuade me and the white lady I brought along from attending it. He pointed out to us that curiosity in this connection was no good, and that the spirits would not appear if the whole audience did not join in prayers to them. Cf. also W. R. Hurt, "A Yuwipi Ceremony at Pine Ridge" (Plains Anthrop., vol. 5: 10, 1960), p. 52.

3 It is interesting to observe that the sweat-bath rite which was formerly performed in a separate hut outside the spirit lodge has now been incorporated in the main ceremonies. Concerning the sweetsage, this was probably Artemisia ludoviciana, a herb that often serves as incense among northern Plains Indians. 
to a series of jars standing on a line. The string is stretched between them some few inches above the ground and carries 147 small red bags filled with tobacco. Beside his blanket, but inside the enclosure, the medicine-man arranges a little altar, provided with, inter alia, feathers, sacred pipes, tobacco and gourds. He thereafter sets a piece of sagebrush on fire and makes the incense pass over the sacred objects of the altar, at the same time as the thundering sounds of the drum fill the room and the harsh voices of the drummers reach the ceiling. Mark fetches his two ceremonial pipes and points first one, then the other in the direction of the four cardinal points and over the heads of the assembly, making blessing hand movements.

After these preliminary rites there takes place a sacrificial ceremony of a type which occurred in the Sun Dance in the old days. A young daughter of Buster and Helen Crispin, Helena, steps forward, withdraws her moccasins and places her feet on the blanket, at the same time looking towards the west. The medicine-man comes closer, strokes her left arm with sagebrush, raises his hand and prays over her. Thereafter he brings out a razor, and under the deafening roar of the drums he cuts thin slices of skin and flesh from the girl's upper arm. She makes faces, but apparently does not utter a sound; her blood pours out of the wounds, while the assembled, still seated, pray with lowered heads. After a while Mark nods as a sign that her torture is over. She returns to her seat, and is relieved by Mark's wife who now steps forward to suffer the same painful procedure. The sacrificial flesh of the two women is then collected and placed in a little gourd that has its place on the altar. The spirits have received their tribute.

It is now time for the main performance, the shamanizing. The medicineman who is stripped to the waist stands up on his carpet, whereupon two men approach him and wrap him up very tightly in a blanket. Then they bind him with ropes all over the body, and his hands are tied together behind his back so tightly that they become red. At the same time Mark starts calling on his guardian spirits in a tense, strained voice. Now and then he disrupts his singing with the voice of the owl: "hu, hu". The assistants cover up his face, but his singing continues, although with a partly stifled voice. Finally, the medicine-man is placed on the floor, lying on his face. And then the light in the ceiling is extinguished.

There follow four steady beats on the drums, then the tempo becomes 
faster and faster working up to a frenzy, and the room resounds with the intense singing of those present. After a few minutes have elapsed in the dark something seems to happen, ${ }^{1}$ and suddenly one can hear a rattle jingle in the midst of the turmoil. It seems to move around the room at the level of a man's height. The drums and the singing cease, and the only thing that may be perceived by the ear is the quiet moaning of the medicine-man, still, as far as I can judge, emanating from the level of the floor. The spirits have arrived.

Helen Crispin's voice breaks the weird silence. "Oh, Skadi and you other spirits, please, pity us. We are here to ask you to take care of and to cure Steve, my brother-in-law, who is very ill. Help him to get well. We believe in you, Skadi. Please cure him, allow him to be with us, let him take care of his family. Skadi and you other spirits, we ask you from all our heart to make him well". One can hear agreeing mutterings from the assembled, even an "amen" here and there. Helen prays again: "Skadi, take away the evil from Steve, place it somewhere out in space where there are no people and where nobody may be hurt by this evil. And think, Skadi, of my niece who is sick and weak, and cure her". Other persons also send up similar prayers, asking for the cure of their sick kinsmen. They ask Skadi if he will make them well, and beseech him to give counsel whether or not they should send their sick youths to school.

Suddenly, Mark says something under his blanket. Those seated very close to him apprehend that the Thunder spirit has arrived, not, on the other hand, the longed-for Skadi. The latter is expected from Rapid City in the Black Hills, and because of his distant abode it takes time for him to arrive. Some minutes are spent in eager expectation. Then Mark starts singing, the drums are sounded again, but more violently than before, and men and women sing with all their voices-indeed, the noise is deafening. Now the cry of an owl breaks through the turmoil. It is Skadi who has arrived; being a ghost he chooses the apparition of the owl. Heavy steps resound from the boards of the floor. Sighs are perceived from the centre of

1 According to what Crispin and others said one can see blue and green sparks when the spirits enter. (Cf. Hurt, op. cit., p. 5I). My own experiences-however they may be explained-were restricted to feeling a strange draught along the wall and shivers running up and down my spine. 
the room where the medicine-man is supposed to be lying. All the rest is now silence.

At the request of Buster Crispin the assembled move away some inches from the walls in order to make it possible for the spirits to pass freely in and out. Mark's voice is again heard all over the room. He announces what he has been told (not audible to the rest of us) by Skadi. The girl N.N. will have a baby. "Ugh", the listening crowd comments. Skadi promises to see to the patients who have been prayed for, but he will first treat Steve. The latter is ordered by Crispin to rise to his full length against the wall. Again there is singing and drumming, until Mark announces that Steve has been cured and that Skadi has left to visit the sick ones at the hospitals. The sound of an airplane can be vaguely perceived by all present. Mark bursts into laughter: "Skadi regrets that he can't take the airplane, he missed it". There is mirth everywhere, a sort of release from all the preceding tensions. ${ }^{1}$ Mark adds that the séance may be adjourned for some minutes, since Skadi is not present any longer and will be away for a while.

When the light is turned on Mark is found seated on his carpet which he has rolled up. Drops of perspiration fall from his naked back. The rope that had fettered him is lying neatly coiled at his feet, the blanket is away, it had been thrown out in the dark and had landed among the audience. ${ }^{2}$ Crispin is satisfied: this is how it should be done, he says, this is how the old-timers did it. "The Whites don't catch anything when they take photographs, and therefore it is meaningless to photograph". 3

It is now past mid-night. Soon, the light is put out again. There is, once more, singing and drumming, thereafter the rattle is sounded again. Skadi announces through Mark that he has helped the sick and cured them. Steve will get well, but in future he must think of Skadi and take care of himself. This information from the spirit is followed by happy cries of delight from

1 The occasional outbursts of laughter during the conjuring ceremony have also been observed by other authors, cf. for instance Hallowell, op. cit., pp. $44 \mathrm{f}$.

a The blanket, in fact, hit the white lady whom the author had in his company. It is known from other similar ceremonies that it sometimes falls down on somebody who is unbelieving; see W. R. Hurt and J. H. Howard, "A Dakota Conjuring Ceremony" (Southw. Fourn. of Anthrop., vol. 8: 3, 1952), pp. $292 \mathrm{f}$.

${ }^{3} \mathrm{He}$ is referring to photographic experiments during spiritualistic séances in Rapid City. 
those present, and above all the humming sounds Helen's quiet voice: "Thank you, thank you, Skadi".

Mark announces that Skadi is now leaving us. After some minutes the light is turned on again. The séance is at an end. What remains pertains to the common Indian feast traditions: the feathered ceremonial pipes pass around among the assembled, and a feast is served by Crispin's daughters. It was 2.45 o'clock in the morning when the meeting was dissolved.

As far as I know, Steve Duran kept fairly well henceforth; at least he did not get worse. The believers said, of course, that he had become better, and it is certainly not impossible that this was so. ${ }^{1}$ Throughout the autumn and winter Mark remained among the Arapaho, and he was very popular since he never charged his clients for the services he rendered them, thereby differing from other medicine-men among the Dakota Sioux. ${ }^{2}$ I was informed that the spirits had imposed many taboos on him, amongst other things, the prohibition to make money in his work as wapiye, medicine-man.

During the years which have since elapsed the type of medicine ceremony here described has gained a secure position among the Arapaho, and according to the latest information at my disposal it is now performed by a young Arapaho Indian whose reputed capacity to work miracles has induced Indians from many tribes to visit the Wind River Reservation. ${ }^{3}$

\section{Old and New Forms of the Spirit Lodge Ceremony}

The ceremony described above is a variant of the great ceremonial complex Spirit Lodge. This variant is called yuwipi in the Dakota language, a word which denotes the binding and wrapping up of the medicine-man, and it is

${ }^{1}$ On the other hand, Buster Crispin, the host of the ceremony, passed away during the Sun Dance the following year.

2 In most conjuring séances of this type it is a common thing that the medicineman abstains from fees.

${ }^{3}$ See also concerning this V. Dusenberry, The Montana Cree: A study in religious persistence (Acta Universitatis Stockholmiensis, Stockholm Studies in Comparative Religion, vol. 3, 1962), p. I72. The reader is reminded of what was said above concerning this medicine rite as a nativistic ceremony. According to Dusenberry, the interest in the Spirit Lodge is growing among all the northwestern Plains tribes. The Cree in Montana who gave up the ceremony in 1904 or perhaps a little later, reintroduced it in 1945 (op. cit., pp. 167 f.). Cf. below concerning the spread of the rite in its modern Dakota form. 
performed among the Dakota Sioux, in particular the Oglala branch. ${ }^{1}$ What differentiates the yuwipi from other Spirit Lodge performances is, above all, the intricate ritualism with much ceremonial paraphernalia and-in modern times-the location of the ceremony in the quadrangular room of a cottage. 'To these elements may also be added the blood sacrifices.

The exhibition of ritual objects within a square, mentioned above, seems to be an item of the common ritualistic pattern in the Northern Plains. It is possibly related to the Sun Dance altar and other similar ceremonial structures among the Plains Indians² and may, as in the Cheyenne Sun Dance, represent the earth or the universe. ${ }^{3}$ From the formal point of view the yuwipi altar reminds one of the sacred shrines of the Pueblo Indians and may, indeed, be related to these. $4 \mathrm{~A}$ different opinion has been developed by the anthropologist S. E. Feraca who thinks that the earthen altars are variations of the fireplaces among the Indians of the Southeast. ${ }^{5}$

The blood sacrifice was formerly common in the Plains Sun Dance and in the vision quests in this area. ${ }^{6}$ It is of great interest to note that the sacrifice made in the Arapaho-Dakota rite which has been described in this paper corresponds completely with the famous Sioux (Hunkpapa) Chief Sitting Bull's self-sacrifice in the Sun Dance of 1876 : also in this case, slices of flesh and skin were cut out of the arms.?

${ }^{1}$ Hurt \& Howard, op. cit., pp. $286 \mathrm{ff}$; Hurt, op. cit., pp. $48 \mathrm{ff}$.; W. R. Hurt, "Correction on Yuwipi Color Symbolism" (Plains Anthrop., vol. 6:I I, I961), p. 43; S. E. Feraca, "The Yuwipi Cult of the Oglala and Sicangu Teton Sioux" (Plains Anthrop., vol. 6: 13, 1961), pp. 55 ff.; idem, Wakinyan: Contemporary Teton Dakota Religion (Browning, Montana, 1963), pp. $26 \mathrm{ff}$.

2 Cf. R. H. Lowie, Indians of the Plains (New York 1954), p. 170; C. Wissler, North American Indians of the Plains (New York 194I), pp. 129 f.; L. Spier, "The Sun Dance of the Plains Indians: Its Development and Diffusion" (Anthrop. Papers of the Amer. Mus. of Nat. Hist., vol. XVI: 7, New Yotk I921), pp. 47I ff. See also the illustration in G. A. Dorsey, The Arapaho Sun Dance (Field Columb. Mus., Anthrop. Ser., vol. IV, Chicago 1903), pl. LXI, p. Ir8.

${ }^{3}$ G. A. Dorsey, The Cheyenne, II: The Sun Dance (Field Columb. Mus., Anthrop. Ser., vol. IX: 2, Chicago 1905), p. 146.

1 Cf. E. C. Parsons, Pueblo Indian Religion (Chicago r939), vol. I, pp. 353 ff., II, pp. $956 \mathrm{f}$.

5 Feraca, "The Yuwipi Cult" etc., p. I55.

6 Spier, op. cit., pp. 492 f. Cf. W. C. MacLeod, "Self-Sacrifice in Mortuary and Non-Mortuary Ritual in North America" (Anthropos, vol. 33, 1938), pp. $349 \mathrm{ff}$.

7 S. Vestal, Sitting Bull, Champion of the Sioux (2nd ed., Norman I957), pp. 149 f. 
The present habit of arranging the rite in the room of a wooden building, the most common dwelling among the Arapaho of today, is of rather recent origin. In the old days the performance took place in a lodge (tipi), and it could frequently happen that the tent shook in a mysterious way when the spirits entered and departed, or even during the whole ceremony. ${ }^{1}$ These agitations were formerly common in most places where the ceremony occurred. They motivate its most popular name, the "Shaking Tent".

The Arapaho, too, have once known the rite in this form. Bruce Grosbeak, an elderly Arapaho, who died in $195^{6}$ and who had a good knowledge of the old traditions of his tribe, told me that before the turn of the century the Spirit Lodge ceremony was arranged in a tent. The medicine-man was tightly tied to the base of a lodge pole, and the spirits entered through the smoke hole; the audience could hear their voices from the top of the tent.

Such séances were reported already in the beginning of the seventeenth century by Samuel de Champlain and Father Le Jeune who had found them in the territories of the Algonkian Indians. 2 They still occurred in this area until very recent times, and most probably exist there even today. The Shaking Tent was, as we shall see, also common in the northern Plains and Plateau areas farther west. In most cases the ceremony was held in a tent which had been raised for the purpose, and not infrequently we are informed that the medicine-man performed his magic tricks in a small, closed tent which was put up inside a large lodge. Sometimes the medicine-man was not tied up. Otherwise, the similarities between the oldest known Spirit Lodge performances and the yuwipi rite which has just been described were so great that it must be taken for granted that both of them belong to a very

1 See G. Pond, "Dakota Superstitions" (Minnesota Hist. Collections, vol. 2, 1889), pp. $249 \mathrm{f}$.

2 H. P. Biggar (ed.), The Works of Samuel de Champlain (Publ. of the Champlain Soc., vol. II, Toronto I925), pp. $86 \mathrm{ff}$. (the same text also to be found in vol. IV, Toronto 1932, pp. 85 ff.); R. G. Thwaites (ed.), The fesuit Relations and Allied Documents, vol. 6 (Cleveland 1897 ), pp. I63 ff., vol. I 2 (Cleveland 1898 ), pp. I 7 ff. (Le Jeune). Champlain's experience is from I6o9, Le Jeune's from I634. The first picture of a Spirit Lodge rite appears in H. R. Schoolcraft, Historical and Statistical Information Respecting the History, Condition and Prospects of the Indian Tribes of the United States, vol. V (Philadelphia r860), P1. 32; it shows a cylindrical medicinelodge in which the spirits are conjured up and probably refers to the Ojibway; cf. the text, pp. $42 \mathrm{Iff}$. 
old, fixed shamanistic tradition. It is possible to say that the yuwipi today supplies the form in which this tradition can survive; it has, so to speak, transferred shamanism from the tent milieu of the nomad to the modern, urbanized milieu. ${ }^{1}$ The yuwipi rite has recently expanded, and not only among the Arapaho. At present it is on its way to penetrate Sioux reservations where the secret of the Shaking Tent was forgotten many years ago. ${ }^{2}$ It seems that nowadays the yuwipi performance is the most vital element of the old pagan religion among the Dakota. ${ }^{3}$

In this connection we must abolish the suspicion that this medicine ceremony, in any case in its yuwipi form, has received a decisive influence from modern spiritualistic séances. There are, certainly, reasons for assuming such influence, as when, for example, the medium in both ceremonies keeps in contact with a spirit control who is the ghost of a deceased person-in the Arapaho ceremony even the ghost of a White person.4 On the other hand, the presumed connection is impossible in view of the fact that right since the beginning of the I 7 th century the Spirit Lodge ceremony has preserved its tight moulding and has been diffused over a considerable area, as we shall soon see. It is more likely that modern occidental spiritualism has been influenced by American shamanism as this appears in the Spirit Lodge. 5 This is also the opinion of Richard Lambert who points out that both the trick of escaping when being bound up and the custom of giving the controls Indian names have been passed over from American Indian shamanism to modern spiritualism. ${ }^{6}$ It is appropriate to mention in this connection that the

1 Cf. Hurt \& Howard, op. cit., p. 294: the architectural structure motivates the absence of the shaking trait in the modem yuwipi.

2 Feraca, op. cit., p. I62; Hurt \& Howard, op. cit., p. 288 n. I I.

${ }_{3}$ G. Macgregor, Warriors without Weapons (Chicago r946), pp. 98 f.; cf. Feraca, op. cit., p. 162.

4 Several parallels between the Spirit Lodge and the spiritualistic séances were already pointed out by J. G. Kohl who studied the Ojibway ceremony in the I850's (cf. below).

5 Cf. in this connection the comparisons between modern spiritualism and Siberian shamanism in Findeisen, op. cit., and Stiglmayr, op. cit.

- Lambert, op. cit., p. 128. Another writer goes even further when he claims that the séance-cabinet of modern spiritualism is directly derived from the North American Indian conjuring lodge (D. H. Rawcliffe, Illusions and Delusions of the Supernatural and the Occult, New York 1959, p. 302). The impact of the Spirit Lodge on spiritualistic literature has been discussed by Hallowell (op. cit., p. 2). 
well-known Swedish author and spiritualist Jan Fridegard claims that he has an Indian guardian spirit, the ghost of a medicine-man.1

\section{The Diffusion of the Spirit Lodge Complex}

From the phenomenological point of view the religious beliefs and rites making up the Spirit Lodge constitute a unitary, complex whole. The different elements pertaining to it occur to a surprising extent in a fixed order and clearly delimited from other shamanistic performances. The area of diffusion is, moreover, restricted, or mainly so, to a continuous east-western belt in Canada and the United States. It is thus evident that the Spirit-Lodge ceremonies have a common historical origin. ${ }^{2}$ The efforts made by American anthropologists to establish the roads of diffusion must, however, be considered only partly successful. Not only does every new discovery of the conjuring practice change the earlier historical reconstruction, but also the information available from times past is too scattered to support more than a tentative analysis of this kind.

This does not rule out the possibility that a study of the distribution of the Spirit Lodge may reveal to us where this ceremony had its centre of gravity and, in all probability, its centre of diffusion. Its main area takes in three important cultural regions, the Northeastern Woodland, the Plains and - less intensely, it is true - the Plateau. A separate but major field of distribution is the Eskimo area. Within the main area the ceremonial complex seems to be concentrated to ethnic groups of Algonkian affiliation. It is preferably these tribes who have used the particular, shaking conjuring tent. ${ }^{3}$ The rectangular enclosure of strings and flags in the Arapaho ceremony and in the conjuring performances of other Plains tribes is to all appearances a

1 J. Fridegård, Den gåtfulla vägen (Göteborg 1963), p. 87. Fridegård does not know the name of this spirit. He mentions, however, the names of some other spirits of American Indian origin appearing in the séances he partakes in: Chief Black Eagle, who is a control, and "Kockum", a trickster playing practical jokes during the séance (op. cit., pp. 40, 87).

2 Ray, op. cit., p. 204; D. Collier, "Conjuring among the Kiowa" (Prim. Man, vol. I7: 3-4, I944), p. 45 .

s Hallowell, op. cit., p. 14; R. Flannery, "The Shaking-Tent Rite among the Montagnais of James Bay" (Prim. Man, vol. I2: I, 1939), p. I4 ("an exclusively Woodland Algonquian usage"). 
substitute for the shaman's tent among the Algonkian tribes. These and other facts seem to point to the main role played by Algonkian Indians in the dissemination of the complex phenomenon.

In the Northeastern Woodland the Spirit Lodge ceremony is known from a series of Algonkian tribes and ethnic groups: the Cree, Mistassini, NaskapiMontagnais, Ojibway. ${ }^{1}$ From the 17 th century onwards the evidence is rich from these groups, so rich that it is possible to consider the Northern Algonkian Spirit Lodge as the high mark of the ceremonial complex. In later times it appears that almost every small band had the séance. ${ }^{2}$ In the periphery of the area the ceremony, strange to say, is missing among the Coast Algonkian Indians, ${ }^{3}$ whereas we find it among the Menomini (Central Algonkian). ${ }^{4}$ It is not improbable that it has reached the latter from the Northern Algonkian tribes. The existence of a shaking-tent rite to the south of this area, among the Creek, seems rather enigmatic. 5 One could possibly expect that the Southern Algonkian tribes, in particular the Shawnee, should have brought the ceremony to some southern peoples. But this is not the case, for the Shawnee and their neighbours do not know it. We shall return to this problem later on.

It is quite probable that the Spirit Lodge was spread over the Plains by

1 Source material for the Cree, Naskapi-Montagnais and Ojibway will be found communicated in Cooper, op. cit., pp. $78 \mathrm{ff}$., Hallowell, op. cit., pp. $14 \mathrm{ff}$., $35 \mathrm{ff}$., and Ray, op. cit., pp. 205 f., 208 n. I I. Additional information on the Ojibway may be found in M. I. Hilger, "Chippewa Child Life and Its Cultural Background" (Bur. of Amer. Ethnol., Bull. I46, Washington 195I), pp. 75 ff. Concerning the Mistassini, see M. \& J. Rousseau, "La Cérémonie de la tente agitée chez les Mistassini" (Actes du XXVIII Congrès Intern. des Américanistes, I948), pp. 307 ff.; J. Rousseau, "Rites païens de la forêt québécoise: la tente tremblante et la suerie" (Cahiers des Dix, 18-19, Montréal 1955), pp. 129 ff.; J. A. Burgesse, "The Spirit Wigwam as Described by Tommie Moar, Pointe Bleue" (Prim. Man, vol. I7: 3-4, 1944), pp. $50 \mathrm{ff}$.

2 Cooper, op. cit., p. 79.

3 Hallowell, op. cit., p. I4 n. 21; Cooper, op. cit., p. 82; R. Flannery, "The Culture of the Northeastern Indian Hunters: A Descriptive Survey" (Man in Northeastern America, ed. F. Johnson, Andover 1946), pp. 264 f.

"W. J. Hoffman, "The Menomini Indians" (Bur. of Amer. Ethnol., 14th Ann. Rep., Pt. I, Washington I 896), pp. I42 ff. The forms taken by Huron and Iroquois shamanism resemble certain aspects of Algonkian shamanism, but lack the Spirit Lodge features; see G. P. Kurath, "Effects of Environment on Cherokee-Iroquois Ceremonialism, Music, and Dance" (Bur. of Amer. Ethnol., Bull. I8o, No. I8, Washington 1961), p. 183 .

5 Cooper, op. cit., p. 83 .

4-654204 Edsman 
stimulus from the Algonkian tribes in this area, the Plains Cree, the Cheyenne, Arapaho, Gros Ventre and Blackfoot.1 It gained a firm footing among the northern Sioux Indians, that is, several Dakota groups-the Wahpeton, Sisseton, Mdewakanton, Yankton, Yanktonai, Teton (to whom the Oglala belong) - and the Assiniboin, Mandan and Crow.2 Finally, the ceremony reached the Arikara at the Upper Missouri and the Kiowa on the southern Plains. ${ }^{3}$ The latter, isolated case may seem surprising. It should however be observed that the Kiowa some centuries ago probably maintained their existence in the northern Plains. ${ }^{4}$ Lowie has noted down some few cultural elements joining the Kiowa with the Crow. ${ }^{5}$ It is now possible to add to them the Spirit Lodge.

Some Plains tribes, perhaps the Blackfoot in the first instance, were probably responsible for the diffusion of the conjuring lodge to two eastern Plateau tribes, the Kutenai in British Columbia and the Salish-speaking

1 Besides the source material quoted in Collier, op. cit., pp. $47 \mathrm{f}$., and Ray, op. cit., consult the following works: on the Plains Cree, Dusenberry, op. cit., pp. I66 ff.; on the Gros Ventre, Cooper, op. cit., pp. 6o ff., and R. Flannery, "The Gros Ventre Shaking Tent" (Prim. Man, vol. I7: 3-4, I944), pp. 54 ff., cf. also A. L. Kroeber, "Ethnology of the Gros Ventre" (Anthrop. Papers of the Amer. Mus. of Nat. Hist., vol. 1: 4, New York I9o8), p. 276; on the Blackfoot, Cooper, op. cit., pp. 77 f., and Chief Buffalo Child Long Lance, Long Lance (New York I 928), pp. 5 I ff. There is no earlier information on Arapaho jugglery in the ethnographic literature.

2 Source material for most of the Dakota groups may be found listed in Hurt \& Howard, op. cit., p. 287. Concerning the Wahpeton, see also W. D. Wallis, "The Canadian Dakota" (Anthrop. Papers of the Amer. Mus. of Nat. Hist., vol. 4I: I, New York I947), pp. Io2 f. As to the Assiniboin ceremony, see the sources noted down in Collier, op. cit., p. 47 n. 5 ; see also Cooper, op. cit., p. 78 , and J. L. Long, The Assiniboines (ed. M. S. Kennedy, Norman I96I), pp. I62 ff. The Mandan ceremony is described in A. W. Bowers, Mandan Social and Ceremonial Organization (Chicago I950), pp. 179 f, the Crow ceremony in R. H. Lowie, "The Religion of the Crow Indians" (Anthrop. Papers of the Amer. Mus. of Nat. Hist., vol. 25: 2, New York I 922), pp. 380 f., and idem, The Crow Indians (New York I935), pp. 70 f.

${ }^{3}$ For the Arikara, see H. M. Chittenden \& A. T. Richardson (ed.), Life, Letters and Travels of Father Pierre-Fean De Smet (New York I 905), vol. I, pp. 250 f.; for the Kiowa, see Collier, op. cit.

4 W. R. Wedel, "An Introduction to Kansas Archeology" (Bur. of Amer. Ethnol., Bull. I74, Washington I959), pp. 78 f.; G. E. Hyde, Indians of the High Plains (Norman 1959), pp. I $37 \mathrm{ff}$.

5 R. H. Lowie, "Alleged Kiowa-Crow Affinities" (Southw. Fourn. of Anthrop., vol. 9: 4, I953), pp. 357 ff.; idem, "The Relations between the Kiowa and the Crow Indians" (Société suisse des américanistes, Bull. no. 7, Genève I953), pp. I ff. 
Colville in Washington. ${ }^{1}$ There are no traces of the ceremony farther west, unless we include the shaking post in the Cannibal dancing rites of the central and northern Kwakiutl (Wikeno, Bella Bella and Haisla). It was common usage here to tie the future shaman to the loosely set pole during the initiation rite. ${ }^{2}$ The parallel with the Spirit Lodge is, however, very farfetched and certainly does not prove any immediate connections.

Against the distributional background as drawn up above it may seem surprising to instance the occurrence of a Spirit Lodge ceremony among the Eskimo, particularly the Central Eskimo. ${ }^{3}$ It is, however, possible to find evidence for a direct communication between the Eskimo and the conjuring tribes to the south. Theoretically, there may have existed two channels of diffusion, via the Naskapi or via the Cree. As concerns the Naskapi, they are in touch with the Eskimo on their northern boundary. ${ }^{4}$ Cree shamans have performed Spirit Lodge séances as far north as the White Sands at the Mackenzie River, Lake Athabaska and the Athabaska River. ${ }^{5}$ It is doubtful, however, whether they have come in closer contact with the Eskimo, from whom they were separated by the Athapascan tribes to the north and east. The evidence is contradictory where the dedication of the latter to the Spirit Lodge practice is concerned. Cooper assures us that the Chipewyan lacked the ceremony, even where they bordered on the Cree.6 Regina Flannery

${ }^{1}$ Cf. Ray, op. cit., passim, and see the following sources: A. F. Chamberlain, “Kootenay 'Medicine-Men"' (Journ. of Amer. Folklore, vol. I4, I901), pp. 95 ff.; H. H. Turney-High, "Ethnography of the Kutenai" (Amer. Anthrop. Ass., Memoirs, vol. 56, r94I), pp. $174 \mathrm{ff}$; W. Cline et alii, The Sinkaietk or Southern Okanagon of Washington (General Series in Anthrop., vol. 6, Menasha 1938), pp. I52 f.

${ }^{2}$ Ph. Drucker, "Kwakiutl Dancing Societies" (Anthrop. Rec., vol. 2: 6, Berkeley and Los Angeles 1940), pp. 204, 208 f., 216.

s See e.g. F. Boas, "The Central Eskimo" (Bur. of Amer. Ethnol., 6th Ann. Rep., Washington r 888), pp. 593 f.; K. Rasmussen, "Intellectual Culture of the Iglulik Eskimos" (Rep. of the Fifth Thule Exp., vol. VII: I, Copenhagen 1929), pp. I23 ff.; G. Holm, "Ethnological Sketch of the Angmagssalik Eskimo" (Meddelelser fra Grønland, vol. 39: r, København I9 14), pp. 9o ff. Cf. also A. Hultkrantz, "Die Religion der amerikanischen Arktis" (Die Religionen der Menschheit, vol. 3: Die Religionen Nordeurasiens und der amerikanischen Arktis, Stuttgart 1962), p. 405.

${ }^{4}$ L. M. Turner, "Ethnology of the Ungava District, Hudson Bay Territory" (Bur. of Amer. Ethnol., I Ith Ann. Rep., Washington r894), p. I84.

5 Cooper, op. cit., pp. 79, 82; A. K. Black, "Shaking the Wigwam" (The Beaver, Dec. 1934).

- Cooper, op. cit., pp. 82 f. Cf., however, a similar shamanistic rite in K. Birket- 
also denies its existence among the Chipewyan and adds that, although it does occur among the Beaver, it has only been observed among those Beaver Indians who have been strongly influenced by the Cree. ${ }^{1}$ On the other hand, a traveller in the Great Bear Lake area in the middle of last century, W. H. Hooper, saw there a conjuring lodge, probably belonging to the Satudene. ${ }^{2}$ Furthermore, the medicine-men among the Hare and Loucheux (Kutchin, or rather a band of mingled Hare and Kutchin) are reported to have been suspended in the air to promote their communion with the spirits-something which could be interpreted as a Spirit Lodge seance. ${ }^{3}$ It is, of course, possible that they as well as the Satudene had been influenced by their close neighbours, the Mackenzie Eskimo. In this connection it should also be pointed out that the "rope-trick", i.e. the shaman's mysterious release from the mat and the ropes in which he is entangled, was once known to the Tlingit of Sitka. ${ }^{4}$

Although the link through the Athapascan tribes cannot be proved, it seems probable that the Eskimo and Algonkian-Plains-Plateau conjuring practices once belonged together; they may be considered branches of the same fundamental conjuring complex. From all the evidence the Algonkian groups and the Eskimo must be the originators of the complex in North America. Since it shows a remarkable uniformity over a vast area, despite important variations in certain details, the hypothesis of a rapid dissemination and a single origin is justified. There is, however, no clue to its age which may be quite considerable. The theory has been developed that the Spirit Lodge was created by the Central Algonkian tribes together with their wellknown medicine society and the vision quests of children. ${ }^{5}$ This is not con-

Smith, "Contributions to Chipewyan Ethnology" (Rep. of the Fifth Thule Exp., vol. VI: 3 , Copenhagen I930), p. 82.

1 R. Flannery, "The Shaking-Tent Rite among the Montagnais" etc., p. 14.

2 C. B. Osgood, "The Ethnography of the Great Bear Lake Indians" (Nat. Mus. of Canada, Ann. Rep. for 193 I, Ottawa 1932), p. 48.

3 D. Jenness, The Indians of Canada (Nat. Mus. of Canada, Bull. 65, Ottawa 1934), p. 395; cf. also C. Wissler, The American Indian (3rd ed., New York r950), p. 203.

4 A. Krause, Die Tlinkit-Indianer (Jena 1885), pp. $286 \mathrm{f}$. (English transl. The Tlingit Indians, Seattle r956, p. I96).

5 W. Müller, Die Religionen der Waldlandindianer Nordamerikas (Berlin 1956), pp. $206 f$. 
vincing, partly because it does not account for the Eskimo cases and partly because the Spirit Lodge is intrinsically a ritually fixed form of a more general conjuring practice.

It is possible that both the Creek and the Kwakiutl performances mentioned in the foregoing represent this more general form. Further examples of the latter may be found in the Southwest and in South America. Clairvoyant medicine-men among the Maricopa and other Yuman tribes in the Southwest (Yavapai, Walapai and Mohave) went into a trance in a special hut, among the Maricopa built inside the meeting house, and were possessed by spirits who prophesied the future or revealed some sickness. ${ }^{1}$ Among the Cuna, Isthmus of Panama, the medicine-man was formerly seated behind a partition when he had his nightly séances with the spirits, and similar performances occurred also among the Cágaba in northern Colombia and the Caribs in the northern parts of South America. ${ }^{2}$ The Manasí in Bolivia arrange divining ceremonies in the chief's large assembly hall. A ceremonial leader, mapono, takes his seat behind a curtain, calls on the gods and consults them concerning rain, harvest, hunting luck etc. His questions and the answers of the supernatural beings form a quick dialogue completely audible to the audience on the other side of the curtain. The big building is shaking both at the arrival and the departure of the spirits. ${ }^{3}$ There are other South American instances of the same general type. ${ }^{4}$

We also find similar examples outside of the American continent. Hallowell mentions a conjuring performance among the Semang of the Malay Peninsula, quoting Schebesta and Evans. 5 The construction of the conjuring hut, the turmoil of the spirits and the curative and clairvoyant functions of the

1 See especially L. Spier, Yuman Tribes of the Gila River (Chicago 1933), pp. 292 f., and A. L. Kroeber, "Ethnographic Interpretations" (Univ. of Calif. Publ. in Amer. Archaeol. and Ethnol., vol. 47: 2, Berkeley and Los Angeles 1957), pp. $226 \mathrm{ff}$.

2 S. H. Wassén, "Cunaindianernas medicinmän och deras värld" (Nytt och nyttigt, no. 3, r96r, Göteborg I96r), p. I9.

3 A. Métraux, "The Social Organization and Religion of the Mojo and Manasi" (Prim. Man, vol. I6: I-2, 1943), pp. 22 f.

4 Cf. J. H. Steward, Handbook of South American Indians (Bur. of Amer. Ethnol., Bull. I43, Washington), vol. II (1946) pp. 302 ff.: "Inca"; vol. V (I949) p. 594: “Tupinambá".

5 P. Schebesta, Bei den Urwaldzwergen von Malaya (Leipzig 1927); I. H. N. Evans, The Negritos of Malaya (Cambridge 1937). 
medicine-man in action remind him of the Saulteaux Spirit Lodge. He continues, however, "I am not citing these analogies in order to raise the question of any possible historical connection, but they do seem interesting because, so far as I know, similar parallels do not occur in the Boreal regions of Asia. If they did, it would be difficult to dismiss the possibility of historical connections with North America". 1 But indeed, North Asiatic parallels do exist! A very interesting conjuring performance from the Yalkut was described at the turn of the century by Sieroszewski. It is true that both the conjuring booth and the shaking are missing, but we find the binding of the shaman ("pour le retenir dans les cas où les esprits tenteraient de l'enlever"), the dramatic entrance of the spirits with much noise, curing and prophesying, etc. ${ }^{2}$ Moreover, the leading guardian spirit is here as in many cases in the American conjuring lodge a deceased person, usually a shaman. ${ }^{3} \mathrm{~A}$ ghost is also the chief spirit in a Chukchee séance that shows many features of the Spirit Lodge: the sudden sounds of the voices of the spirits all over the dark room, the shaking of the lodge, throwing of articles, etc. ${ }^{4}$ It is important to note that Lowie presumed ancient historical connections between northern Asia and North America, inter alia by uniting the Chukchee performance with the Spirit Lodge performance. 5 The Eskimo jugglery should, then, be considered the connecting link.

This reconstruction seems most probable. We can go even further. The North American séances should in my opinion be judged as ritually patterned specific forms of a jugglering complex spread not only in the northern parts of Asia and America, but also in South America and Southeast Asia. The reiteration of certain conspicuous elements, for instance the violent entrance

${ }^{1}$ Hallowell, op. cit., p. I4 n. 20. Cf. also T. M. Fraser, "Spiritualistic Ritual in Thailand" (Intern. Fourn. of Parapsychology, vol. 5: 4, I963), pp. $400 \mathrm{ff}$.

${ }^{2}$ W. Sieroszewski, "Du Chamanisme d'après les croyances des Yakoutes" (Revue de l'hist. des rel., t. 46, Paris 1902), pp. 325 ff. Cf. also A. F. Anisimov, "The Shaman's Tent of the Evenks and the Origin of the Shamanistic Rite" (Studies in Siberian Shananism, ed. H. N. Michael, Toronto 1963), pp. Ioo ff. (description of a Tungus shamanistic performance).

3 Sieroszewski, op. cit., pp. 31 2, 3 I4.

4 W. Bogoras, "The Chukchee" (Amer. Mus. of Nat. Hist., Memoirs, vol. I I: "The Jesup North Pacific Exp.", vol. 7, New York 1907), pp. $434 \mathrm{ff.}$

5 R. H. Lowie, "Religious Ideas and Practices of the Eurasiatic and North American Areas" (Essays Presented to C. G. Seligman, London 1934), p. I88. 
of a crowd of spirits, the shaking of the tent and the binding of the medicineman, make a common origin probable. It is of course useless to speculate about the place of this origin. In view of the data collected here one could think of a Circumpacific rite complex, but the question cannot be settled until further research work on its distribution in the Old World has been done.

It is as difficult to decide the age of this wide complex. Discussing the Chukchee ceremony Eliade asserts that it has no original touch. "On a l'impression", he says, "que la technique extatique est en décadence, les séances chamaniques se réduisant la plupart du temps à l'évocation des esprits et à des prouesses fakiriques". 1 This would mean that the conjuring ceremony should be judged as a later development of the great ecstatic séance with imaginary extra-corporeal soul-journeys. Eliade is here of course proceeding from his general theory concerning the character of the original, genuine shamanistic trance. He is quite right in his opinion as far as the great shamanistic ecstasy is concerned, for, as Miss Czaplicka testifies, '"The modern shamans actually 'sink' very seldom, but they know that it was done in the old days". ${ }^{2}$ It is, however, important to note that the Spirit Lodge ceremony is an altogether different complex, a particular form of shamanism where (usually) the intense ecstasy has no necessary function. Therefore, a comparison between the two forms of shamanistic expression cannot give us any clue as to the age of one or the other.

\section{The Position of the Spirit Lodge in American Shamanism}

In order to establish the place of the Spirit Lodge within the North American shamanism it is necessary to discuss some of the more diagnostic traits of the former. This can only be done very summarily since space prohibits a more comprehensive analysis; I hope however to be able to revert to the subject more closely in a future treatise.

The following points seem to be of particular interest in the present connection: the ecstasy; the shaking of the tent and other shamanistic tricks;

1 Eliade, Le Chamanisme etc., p. 23 I; cf. pp. 232 f.

2 M. A. Czaplicka, Aboriginal Siberia (Oxford I9 14), p. 232. 
the nature of the spirits; the suspension of the medicine-man; the occurrence of soul-flight; and the way of curing.

(I) The ecstasy. Opinion is divided whether the conjuring medicine-man 1 is in a state of ecstasy or not. Quoting Shirikogoroff's pronouncement that the Tungus shaman falls into ecstasy Hallowell says, "So far as I know, nothing of this sort is believed to happen to Saulteaux conjurers, nor do I think that trance actually takes place". ${ }^{2}$ It is more than probable that Hallowell has been influenced in his judgement by the rather frank statement of an occasional conjurer (he had tried only once) that he himself had made the lodge shake and the voices sound. ${ }^{3}$ This statement is, however, definitely an exception; most conjurers believe that the spirits act without their interference. ${ }^{4}$ Hallowell also refers to the normal mental make-up of the conjurers, as also other investigators do, apparently in the belief that ecstatic shamanism is combined with an abnormal, pathogenic personality structure. ${ }^{5}$ The absence of the trance is also taken for granted by other researchers, e.g. Cooper for the Algonkian tribes and Hurt and Howard for the Dakota. ${ }^{6}$

Other observers testify, however, that ecstasy has been part of the ritual. Champlain noted how the conjurer works himself up into a frenzy, then "se leve sur les pieds, en parlant $\&$ se tourmentant d'une telle façon, qu'il est tout en eau, bien qu'il soit nud". ${ }^{7}$ Le Jeune tells us how the medicine-man became more and more animated and "fell into so violent an ecstasy that I thought he would break everything to pieces". ${ }^{8}$ Speaking about the Mistassini ceremony during the I930's, Burgesse says that "the chant begins slowly and softly, increasing in tempo and pitch to reach a climax when Mictabio

1 It is as a rule a medicine-man who performs the jugglery. Among the Kutenai, however, anyone possessing a guardian spirit could be a conjurer, and among the Cheyenne the latter had to be a layman (Ray, op. cit., pp. 207, 209). It must be recalled, however, that the boundary line between a medicine-man and other visionaries is very slight and sometimes completely disappears, particularly on the Plains.

2 Hallowell, op. cit., p. 13.

3 Op. cit., pp. $76 \mathrm{ff}$.

4 Op. cit., pp. 73 ff.

5 Hallowell, op. cit., p. I3; Cooper, op. cit., p. 8I; Hurt and Howard, op. cit., p. 295 .

6 Cooper, ibid.; Hurt and Howard, ibid.

7 Biggar, op. cit.

8 Thwaites, op. cit. 
[=the control] manifests himself and the shaman is entranced". ${ }^{1}$ The descriptions of the Eskimo performance leave no doubt concerning its ecstatic nature. Ohlmarks, referring to the Menomini rite as described by Hoffman, talks about a modified ecstasy. "Von einer wirklich grossen Schamanenextase ist ja hier nicht die Rede", he says, "wohl aber von einer gewissen Ekstase und Erregtheit, wo die Geister den 'Juggler' inspirieren und ihm die Zukunft entschleiern".2 Lambert, on the other hand, is less inhibited in his general assessment of the Spirit Lodge phenomena. He states that the medicine-man employs a rattle and drum as he chants and howls "in preparation for going into a trance". ${ }^{3}$

It depends of course on our definition of ecstasy whether we can characterize the Spirit Lodge shamanism as ecstatic. Ernst Arbman, our foremost authority on the subject, describes ecstasy as a "total suggestive absorption in the object of belief", an absorption which reveals itself in "a peculiar, strictly organized and intensively clear, conscious and realistic visionary state of dream". ${ }^{4}$ The visions have in certain cases an "almost dazzling inner clairvoyance or illumination", with "actual perceptions of light of a purely hallucinatory or physically sensuous nature". ${ }^{5}$ It is of interest to note that Arbman shows after lengthy investigations that religious ecstasy, although anormal, can in no way be said to presuppose a pathological state of mind or a psychically disintegrated personality system. ${ }^{6}$ This conclusion eliminates the apprehensions of certain anthropologists, referred to above, against associating the conjuring with states of trance.

In view of these definitions it seems justified to consider the Spirit Lodge shamanism an ecstatic performance. ${ }^{7}$ We know for sure that the conjurer, who is certainly no fraud, believes that the mysterious things that happen are the result of the spirits' own activity; it should be impossible for him to

1 Burgesse, op. cit., p. 5 I.

2 Ohlmarks, op. cit., p. 98.

3 Lambert, op. cit., p. 126 .

4 E. Arbman, Ecstasy or Religious Trance, vol. I: "Vision and Ecstasy" (Uppsala I 963), p. XV. Cf. my own definitions in The North American Indian Orpheus Tradition (Statens Etnogr. Mus., Monogr. Ser., vol. 2, Stockholm 1957), pp. $236 \mathrm{f}$.

5 Arbman, op. cit., p. 297.

6 Arbman, op. cit., pp. $215 \mathrm{ff}$.

7 Cf. also Hultkrantz, Les Religions etc., pp. 90, $98 \mathrm{f}$. 
maintain this if he is not himself entranced, i.e. absorbed in this belief. Drumming, shaking of rattles, singing and other suggestive acts produce the preparation for ecstasy. Obvious proofs of the presence of ecstasy are the light visions, the automatic speech, and, where they have possibly occurred, the states of possession.

The light visions are, as mentioned above, a typically ecstatic symptom. They are mentioned in several sources as belonging to the experiences of both the conjurer and his audience-for instance, already in Champlain's description, and as late as in the notes on the Arapaho rite in the present article. It is probable that the audience's visions reflect the suggestive influence of the conjurer who sees the light within the frame of his ecstatic state. ${ }^{1}$ An excellent case of the conjurer's light perceptions is found in Kohl's description of an Ojibway séance (the disadvantage however being that the author received his information second-hand). The medicine-man told Kohl's informant that the top of the lodge in which he made his performance was filled with the voices of the spirits and lit up by a shining light, and the whole universe, heaven and earth, lay open before his eyes.2 Arbman, who quotes this passage, ${ }^{3}$ states that what is here described is "the very ordinary hallucinated light that must be supposed to be present in every really ecstatic vision or inner visionary scenery in the same way as in the natural dream", although the rapid transition from inner darkness to vision makes the light perception more intense in the ecstatic vision than in the natural dream. ${ }^{4}$

The automatic speech functions sometimes in the messages which the spirits give to the public through the medicine-man. It is true that these messages can be delivered in a quiet, natural way and with a voice that sounds normal and talks the same language as the audience. ${ }^{5}$ But in other cases the language of the spirits is unintelligible and has to be translated by

1. Even Le Jeune saw fiery sparks emerging from the top of the lodge, cf. Thwaites, The fesuit Relations, vol. 6, p. I73. A recent observer, Hurt, noted the same thing; see Hurt, op. cit., p. $5 \mathbf{I}$.

2 J. G. Kohl, Kitschi-Gami oder Erzählungen vom Obern See (Bremen 1859), vol. II, p. 78 .

3 Arbman, op. cit., pp. $3 \circ 3 \mathrm{f}$.

4 Arbman, op. cit., pp. $332 \mathrm{f}$.

5 Cf. the Gros Ventre (Cooper, op. cit., p. 67) and the Saulteaux (Hallowell, op. cit., pp. $44 \mathrm{ff}$.). 
the control or the medicine-man. ${ }^{1}$ It is difficult to avoid the conclusion that we have here to do with verbal automatisms on the part of the medicine-man, and such phenomena belong of course to ecstasy.

Neither the light vision nor the automatic speech do as such necessarily presuppose a deeper trance. ${ }^{2}$ It is different when the ecstasy also includes a soul journey or a possessional state. North Asiatic and Eskimo conjuring séances contain in any case the former of these traits (see below, section 5), perhaps also the latter although this is difficult to decide. Possession is an ambiguous concept in most ethnographic texts, sometimes referring to the intrusion of a spirit in the body, at other times referring to the domination of the personality by a foreign spirit which has usurped the place of the ego. From the psychological point of view only the latter definition is important, and it will therefore be used here.

States of possession are, as we know, rather rare in North American shamanism. ${ }^{3}$ The cases which could be adduced in connection with the conjuring ceremony are not very convincing. In the Kutenai and Colville rites, the medicine-man is supposed to be carried away by the spirits and replaced by them; it is doubtful whether this means a case of possession, since the conjurer's body and not only his soul are said to disappear. In a Montagnais séance described by Burgesse the medicine-man was lying unconscious, or seemingly so, while the spirits answered the questions put by the audience. 'Replies to the hunters' questions are always given in the voice of the shaman but Moar [= the informant who had witnessed the séance] explained that it is really Mictabio [= the control] who speaks". ${ }^{4}$ We are after all not told that the medium had been possessed by the spirit, although the situation may be interpreted that way. Le Jeune and several observers after him have noted that the medicine-man, when personifying the spirits,

1 See, for instance, R. Flannery, "The Cultural Position of the Spanish River Indians" (Prim. Man, vol. I3: I, r940), p. I6. These Indians are Ojibway (or OjibwayAlgonkin).

2 Eliade's pronouncement that the shaman's trance always has the same intensity (Shamanism, p. 302) is scarcely correct. See A. Hultkrantz, Conceptions of the Soul among North American Indians (Statens Etnogr. Mus., Monogr. Ser. vol. I, Stockholm I 953), pp. 277 ff. Cf. also Findeisen, op. cit., p. 202.

3 See Hultkrantz, Les Religions etc., pp. $96 \mathrm{ff}$.

4 Burgesse, op. cit., p. 52 . 
talks in a harsh or nasal voice which is otherwise foreign to him. It is obvious that in many cases the medicine-man practises ventriloquism. Kohl, Black, Hallowell and others reveal that there is a dialogue going on, the medicineman speaking from the ground, the spirits, with the medicine-man's twisted voice, speaking from the top of the lodge. ${ }^{1}$ Possession is here no necessary inference, but it cannot be entirely ruled out that it has occurred in some cases. $^{2}$

Possession or no possession, we are satisfied to know that the conjurer is entranced. The trance is produced by different means. Besides drum and rattle, already mentioned, some shamans have resorted to drugs, as for example the old conjurer referred to by Kohl.

(2) The shaking of the tent and other shamanistic tricks. The shaking feature seems to be fundamental in most rites in the Woodland and Plains areas, and it also occurs among the Arctic groups (Eskimo, Chukchee) and in South American conjuring. ${ }^{3}$ Its absence in the modern yuwipi form has here been explained with reference to the construction of the conjuring building; the same explanation applies to its absence among the Mandan and Colville. ${ }^{4}$ From a superficial point of view the shaking is the most impressive feature in the Spirit Lodge; from a functionalistic point of view it is only one of the signs that spirits are present.

Other phenomena testifying to the presence of the spirits are the light visions, the confusion of voices, sounds of tapping and steps on the ground, the throwing around of articles, the liberation of the medicine-man from his bonds and the magical removal of the medicine-man. In this connection only the rope-binding trick will be discussed.

It is usually called the "Houdini trick". It is not always present in the Woodland (Algonkian) performances-indeed, Cooper considers its absence characteristic of the Montagnais and Eastern Cree. ${ }^{5}$ Otherwise, there is in-

${ }^{1}$ See, e.g., Kohl, op. cit., p. 77.

2 Possession has been emphatically denied by some observers: see Rousseau, op. cit., p. I36; Cooper, op. cit., p. 8r. The Arapaho rite described in this article was not associated with the medicine-man's being possessed. As we have seen, possession occurred in the more general conjuring form represented by the Maricopa.

3 Cf. Cooper, op. cit., p. 8I; Collier, op. cit., p. 49.

4 Ray, op. cit., pp. 208 f.; Hurt and Howard, op. cit., p. 294.

5 Cooper, op. cit., p. 8 I. 
formation about its occurrence among all the Algonkian groups having the Spirit Lodge, the Eskimo, and the Plains and Plateau tribes. Some sources underline that the Houdini trick is a secondary feature, and unnecessary. ${ }^{1}$ Cooper suggests that it "had the purpose, overt or covert, of creating or confirming faith in the authenticity of the ghostly visitation".2 As we remember, the binding of the shaman also occurs among the Yakut in Siberia. Its motivation was there that the spirits might carry off the shaman if he were not bound. The same explanation is given by the Central Eskimo; their shaman is bound so that only his soul can move away from the place. This motivation is, however, not sufficient to account for all the American cases in which the medicine-man is untied by the spirits. Although no explicit explanation can be laid forward here it seems fairly certain that the Houdini trick, besides showing the cleverness of the medicine-man and thus strengthening the belief in him and in the rite, demonstrates the presence and interference of the spirits.

The interpretation of the reality behind these shamanistic acts cannot concern us here. The judgements of the observers and writers are very contradictory. Paul Kane, the artist, who witnessed a conjuring ceremony among the Saulteaux in 1848 , was amazed to find that the enclosed shaman could feel the presence of a white man in the dark, and he assures us that the detailed and clear prophecies the medicine-man had told him all came true. ${ }^{3}$ Similar statements have been given by, i.a., Densmore, Hallowell and Dusenberry.4 Eliade considers that the confusion of voices and the liberation of the medicine-man from his bonds are enigmatic phenomena which should if possible be revealed by psychical research. ${ }^{5}$ On the other hand, the most spectacular feature of the conjuring act, the shaking of the lodge, can, according to several observers, be explained with reference to the construction

1 Hurt and Howard, op. cit., p. 292 (Dakota); Dusenberry, op. cit., p. r7o (Plains Cree); Cooper, op. cit., p. 66 (Gros Ventre).

a Cooper, op. cit., p. 66.

3 P. Kane, Wanderings of an Artist among the Indians of North America (Toronto I925), pp. 3 II f.

4 F. Densmore, "An Explanation of a Trick Performed by Indian Jugglers" (Amer. Anthrop., vol. 34: 3, 1932), p. 3 I I Hallowell, op. cit., p. I6 n. 27; Dusenberry, op. cit., p. I68.

5 Eliade, Le Chamanisme, pp. 23 I n. I, 265 n. I. 
of the lodge. These authors do not agree, however, on how the mechanism functioned, and one modern observer can find no clue in the construction of the lodge. ${ }^{2}$ The medicine-men themselves, and even the conjurer mentioned by Kohl who made his statement after he had been converted to the Christian faith, assert that they do not move the top of the lodge. ${ }^{3}$ The value of such pronouncements can of course be contested. As Andrae says, spontaneous experience and simulation go together in religious practitioners with a hysterical—or rather, hysteroform-nature. ${ }^{4}$ At the same time they identify themselves with a role set by their society. ${ }^{5}$

(3) The nature of the spirits. The spirits appearing in the conjuring lodge are of very varying types, but two kinds stand out as being the most common: the spirits of Nature, prevailingly called upon in the eastern part of the conjuring area in North America, and the ghosts, common on the Plains. ${ }^{6}$ In the East, i.e. among the Forest Algonkian groups, Thunder, Turtle and a crowd of animal spirits dominate the scene. Most of the latter belong to the category of "owners" or "masters", each group of animals having a chief.7 This is a very general idea among North American Indians, but it has particularly developed among the Algonkian tribes. The Saulteaux, for instance, apply the concept of "owners" first and foremost to the natural phenomena, the animal and plant species, but they also extend it at the same time to the spirits of the dead. ${ }^{8}$ Thus, in their Spirit Lodge both the masters of the ani-

1 Densmore, op. cit., pp. 3 I 3 f.; Hallowell, op. cit., pp. 73 ff.; Rousseau, op. cit., p. 145 .

2 Black, op. cit.; cf. also Le Jeune's observations on the solidity of the tent in Thwaites, op. cit., vol. 12, pp. 17 ff. See further the criticism of Densmore's hypothesis in Flannery, "The Shaking-Tent Rite", pp. i 5 f., and Hallowell, op. cit., p. 83 n. I29. See also Lambert, op. cit., pp. $127 \mathrm{f}$.

3 Kohl, op. cit., p. 78 . See also Hallowell, op. cit., pp. 74 f., and the quotation from Schoolcraft in M. Mead and R. L. Bunzel (eds.), The Golden Age of American Anthropology (New York 1960), p. 166.

4 T. Andrae, Mystikens psykologi (Uppsala 1926), pp. I39, г7г. An example of a conscious manipulation on the part of the medicine-man may be found in Feraca, "The Yuwipi Cult" etc., p. r6r.

5 Hallowell, op. cit., pp. 75 f.

6 Cooper, op. cit., p. 8I.

7 Cf. A. Hultkrantz, "The Owner of the Animals in the Religion of the North American Indians" (The Supernatural Owners of Nature, ed. A. Hultkrantz, Acta Universitatis Stockholmiensis, Stockholm Studies in Comparative Religion, vol. I, rg6 I), pp. $53 \mathrm{ff}$.

${ }^{8}$ Hallowell, op. cit., pp. 6 f., Io; A. I. Hallowell, "The Spirits of the Dead in 
mals and the master of the dead are invoked. Hallowell gives an interesting sketch of a conjuring performance in which the spirits of deceased relatives were present, their "boss" acting as the control.1

Séances where the dead appear are, however, more characteristic of the performances on the Plains. The crowd of spirits consists of both spirits of Nature, more or less unidentified, and spirits of the dead, often close relatives recently deceased. The control spirit is always, or nearly always, a ghost helper; the Algonkian Cheyenne have, however, the Badger in this role. ${ }^{2}$ Cooper stresses emphatically that no one lacking a ghost helper could conduct the shaking tent rite among the Gros Ventre, no matter how much power he had received by fasting and crying. Most people have guardian spirits representing the realm of Nature, fewer individuals have ghost helpers; and only the latter spirits enter into the Gros Ventre rite. ${ }^{3}$ All over the Plains it seems that the Owl could act as a substitute for the ghost helper. ${ }^{4}$ Actually, here as everywhere in North America-and, for that matter, all over the worldthe owl is the form of manifestation of a dead person.

This association between ghosts and shamans is particularly interesting since, as pointed out by Benedict, "in North America the idea that one may seek tutelaries among the dead is very nearly absent". ${ }^{5}$ There is undeniably a certain difference in the functions of the ghost helper and those of the other guardian spirits: the former gives "knowledge about past, present, future, or distant happenings, and counsel and direction in illness or danger". In short, he imparts information, but does not as such grant power. ${ }^{6}$ The idea of the ghost helper recurs in the Yakut and Chukchee ceremonies, mentioned above. It is tempting to see here an original trait in the conjuring complex, overshadowed by the common guardian spirit idea among the otherwise so conservative Algonkian groups in the East.

Saulteaux Life and Thought" (fourn. of the Roy. Anthrop. Inst., vol. 70: 1, 1940), p. 39 .

1 Hallowell, ibid., pp. 42 ff.

2 G. B. Grinnell, The Cheyenne Indians (New Haven I923), vol. II, pp. I $4 \mathrm{f}$.

3 Cooper, op. cit., pp. 6I ff.; cf. Flannery, "The Gros Ventre Shaking Tent", pp. 54,58 .

${ }_{4}$ Cf. Collier, op. cit., pp. 48,49 . Note that in the Arapaho rite as described in this article the medicine-man hooted like an owl.

5 Benedict, The Concept of the Guardian Spirit etc., p. 47.

6 Cooper, op. cit., p. 64 (referring to the Gros Ventre). 
(4) The suspension of the medicine-man. In some instances we are told that the medicine-man when freed from his bonds is found suspended at the top of the conjuring hut. According to a Blackfoot statement the onlookers can see the shaman "hanging precariously by one foot at the top of the Lodge, stripped as naked as the day he was born". ${ }^{1}$ A similar occurrence is reported from the Teton Dakota. ${ }^{2}$ As far as I know there are no examples from the Woodland distribution area. It is true that the Indians told Le Jeune that the medicine-man's soul left the body and mounted upwards, but this information is probably only a reference to the shaman's amazing ability to throw his voice. ${ }^{3} \mathrm{We}$ are, for instance, reminded here of the way in which Kohl's Ojibway conjuror could make a conversation between himself, lying on the ground, and the spirits entering on top of the tent; 4 or of the Ojibway performance described by Jenness in which Thunder "is at the top, covering it like a lid". 5

The Kwakiutl custom of tethering the shaman-to-be to the pillar of the world has been mentioned earlier. It belongs most probably to a larger cultural connection obtaining in North and South America and in Siberia and characterized by the belief that the centre post of the world as pictured in the cult may serve as a vehicle for the communication between the medicine-man and the spirits in the world above. The spirits may come to the post, or the medicine-man may climb the pole to reach them. ${ }^{6}$ As we have seen, both acts occur, or are supposed to occur, in the conjuring lodge. The spirits enter on top of it, and - on the Plains-the medicine-man climbs up there. There is evidently a liaison here between the climbing-shaman complex and the Spirit Lodge. The Dakota and Blackfoot climbing acts in the Spirit

${ }^{1}$ Chief Buffalo Child, op. cit., p. 57.

2 F. Densmore, "Teton Sioux Music" (Bur. of Amer. Ethnol., Bull. 6r, Washington 19I8), p. 346. Cf. also Chamberlain, op. cit. (the Kutenai).

3 "Some of these Barbarians imagined that this juggler was not inside, that he had been carried away, without knowing where or how. Others said that his body was lying on the ground, and that his soul was up above the tent, where it spoke at first, calling these Genii, and throwing from time to time sparks of fire" (Thwaites, op. cit., vol. 6, p. 167).

4 Kohl, op. cit., p. 77.

${ }^{5}$ D. Jenness, The Ojibwa Indians of Parry Island, Their Social and Religious Life (National Mus. of Canada, Bull. no. 78, Ottawa I935), p. 66.

- J. Haekel, "Zur Problematik des heiligen Pfahles bei den Indianern Brasiliens" (Acts of the 3 Ist Intern. Congr. of Americanists, São Paulo 1955), pp. $229 \mathrm{ff}$. 
Lodge have their close counterparts in the medicine-man's climbing of the centre pole in the Crow and Kutenai Sun Dances. It would be most convenient to see the climbing feature in the Spirit Lodge as a local adaptation on the Plains to the shamanistic climbing complex. Of course, the possibility that the Spirit Lodge as such has its roots in ceremonies connected with this complex cannot be ruled out. ${ }^{1}$

(5) The occurrence of soul-flight. The two Plateau instances of the conjuring complex, Kutenai and Colville, contain a phase in which the medicine-man is said to be carried away to a distant place by the spirits. ${ }^{2}$ It is indeed difficult to form an opinion about the beliefs involved, but from all appearances it was the medicine-man in body, and not his soul, who departed. The difference is, however, not very substantial in this connection, since the free-soul from a psychological point of view is identical with the image of the person. ${ }^{3}$ (It is of course quite another matter what really happened to the medicine-man.)

As just mentioned, above, the conjuror observed by Le Jeune was supposed to have dispatched his soul to the top of the lodge. 4 This was at least the interpretation of Le Jeune's Indian companion, Manitou-Chat-Ché. It is, however, difficult to speak of a real soul-journey in this connection. Furthermore, as emerges from Le Jeune's description of the séance the medicine-man was singing his chants from his place in the lodge until the spirits arrived, whereupon he consulted them. The situation thus did not seem to conform to the idea of a soul-journey.

The Central Eskimo performance gives us more conclusive evidence of soul-flight. Here the shaman's soul flies away to some cosmic region while his body which is securely bound with cords lies inanimate on the ground. After having woken up from his deep trance the shaman tells the audience

1 The climbing of the shaman seems often to be a part of the annual tribal ceremony, cf. Hultkrantz, Les Religions etc., pp. Io7 f. The Colville conjuring seance was apparently held in connection with the Winter Dance which is an annual ceremony related to the Plains Indian Sun Dance.

2 Ray, op. cit., p. 208.

3 Cf. Hultkrantz, Conceptions of the Soul etc., pp. $242 \mathrm{ff}$.; The Kutenai soul beliefs are discussed on pp. $72 \mathrm{f}$.

${ }_{4}$ Cf. above, p. 64 , note 3 , and the words directed to the sceptical Le Jeune by his host: "Enter thou thyself into the tent, and thou wilt see that thy body will remain below, and thy soul will mount on high" (Thwaites, op. cit., vol. 6, p. I69).

5-654204 Edsman 
of his journey in the other world. ${ }^{1}$ His Yakut colleague makes a similar journey to the supernatural world during the conjuring séance.

Although the data are difficult to interpret it would seem that the idea of the soul-journey does not primarily belong to the Shaking Lodge complex, except in its Arctic extension. The common routine is that the spirits called up by the conjuror depart to gain the information which has been demanded. Sometimes they do this on their own initiative, as we have seen in the Arapaho séance, sometimes they are sent away by a commanding spirit, the control, as among the Montagnais. ${ }^{2}$

(6) The curing. Shamans are primarily healers, supernaturally endowed. The juggler in the conjuring ceremony, however, is not necessarily a healer, not, for instance, among the Ojibway where medicine-men are divided into three different categories, healers, conjurers and seers; the members of the Medicine Lodge then are not included here. ${ }^{3}$ If curing occurs in the Spirit Lodge, it is usually of subordinate importance, the greatest weight being laid on the searching for information, for instance, information about the causes and remedy of a certain illness which afflicts somebody in the audience. In the Plains Cree performance the spirits determine the location of a person's illness by hitting his body with a rattle. "Once the exact spot of the sickness has been found, the spirit pounds that particular area quite hard"..4

There are, to my knowledge, only few cases of actual curing in combination with the conjuring act described in our sources. One of them has been demonstrated in the foregoing account of the Arapaho rite; on the whole we receive the impression that the yuwipi performance has inherited the curing activities associated with the shamanism of former days. ${ }^{5}$ Another case emanates from the Ojibway. Jenness tells us that sometimes "the helping spirits cured sickness by exchanging the soul of the patient with that of a man in perfect health; the latter merely felt indisposed for a short time until his new soul regained strength". ${ }^{6}$ The Saulteaux jugglers were formerly

1 Boas, "The Central Eskimo", p. 594.

2 Burgesse, "The Spirit Wigwam" etc., p. 52.

3 Jenness, The Ojibwa Indians etc., pp. $60 \mathrm{ff}$.

4 Dusenberry, The Montana Cree, p. I7r.

- Cf. also Feraca, "The Yuwipi Cult" etc., p. I62, and Hurt and Howard, op. cit., p. 287. See also R. H. Ruby, The Oglala Sioux (New York 1955), pp. 44 ff., 62 ff.

6 Jenness, op. cit., p. 67 . 
capable of restoring the soul to the body of a recently deceased person. In other words, they could cure cases of disease through soul loss by dispatching their supernatural helpers to fetch the patient's soul in the land of the dead.1 (As mentioned above there is otherwise outside the Eskimo area no information of the American conjurer's soul going to the realm of the spirits.) In some places diseases due to witchcraft or the transgression of a taboo can be cured in the Spirit Lodge. If a man has cast a spell over another man the spirits abduct his soul to the conjuring lodge and force him to confess there, whereupon the sick man is said to recover. ${ }^{2}$

It is, however, important to note that information of curing in the conjuring ceremony as such is rare and that the task of the jugglers is primarily to elucidate the nature and treatment of the disease, but not to treat it. The conjurer is a diviner, whether he traces lost objects, discloses past incidents, reveals future events or discovers the cause of diseases.

This summing up of some essential features of the Spirit Lodge complex may now help us to establish its position and relation to shamanism as such, and particularly shamanism in America. The Spirit Lodge is evidently a variety of shamanism characterized by its divining functions. Herein lie its limitations: the shamanistic trance is there, and so are the helping spirits, but the curing activity so typical of shamanism is absent, or principally absent. The act of divining shows a certain affinity with the shamanistic pole-climbing performances and may originally have been related to these. The shaman does not himself make soul journeys to distant regions during the conjuring performance, except among the Arctic peoples where such journeys belong to the regular shamanistic pattern; instead, spirits are summoned and asked to make the necessary expeditions. These spirits represent different categories, but their leader, the control, is a ghost in several quarters. Specific features express the presence of the spirits: the shaking tent, the Houdini trick, the confusion of voices, etc. The spirits visit the shaman whilst the latter is in a trance; where soul journeys and, possibly, possession occur the ecstasy may be very deep, but this is not typical.

${ }^{1}$ Hallowell, The Role of Conjuring etc., p. 64.

2 Jenness, op. cit., pp. 66 f.; cf. Hallowell, op. cit., pp. $60 \mathrm{ff}$. 
It seems realistic to claim that the Spirit Lodge is a particular form of a divinatory practice which has developed within general shamanism, the latter concept used in the sense in which it was defined at the beginning of this article. In the North, its basic structure has been overlayed by Arctic shamanism (cf. the soul journeys and the secondary motivation of the Houdini trick), whereas in the South, that is among Woodland Algonkian groups and Plains-Plateau tribes, it has retained its original character which has become fixed into a rigid ritual pattern. In this way it has become the most spectacular and interesting manifestation of shamanism in North America south of the Arctic zone. 